\title{
音響メタマテリアルによる反射音制御に関する研究
}

\author{
永代 行日出 ${ }^{* 1}$, 細谷 浩之*2, 中野 貴裕 ${ }^{* 1}$
}

\section{A study on acoustic metamaterial to control reflection sound}

\author{
Yukihide NAGAYO*1 ${ }^{* 1}$ Hiroyuki HOSOYA ${ }^{* 2}$ and Takahiro NAKANO*1 \\ ${ }^{* 1,{ }^{*} 2}$ Vibration No.1 Laboratory, Vibration Research Department, Research \& Innovation Center \\ Mitsubishi Heavy Industries, Ltd. \\ 5-717-1 Fukahori-machi, Nagasaki 851-0392, Japan
}

Received: 10 July 2017; Revised: 27 August 2017; Accepted: 22 October 2017

\begin{abstract}
Acoustic metamaterial can have arbitrary acoustic characteristics, and there is possibility to improve acoustic performance of any products dramatically. As metamaterial, many kind of types have been propounded and studied. It is mainly classified into resonance type and non-resonance type. Resonance type metamaterial can change acousic characteristics drastically, but frequency range is narrow. Non-resonance type's acoustic characteristics range is less than resonance type, but it can be changed in broad frequency band. It is a great advantage to use. About non-resonance type metamaterial, it has been already studied to control transmitted sound, but it has not been studied about reflection sound. If reflection sound control become possible, effective method can be chosen to solve noise problem. For example, resonance frequency in a duct will be shifted by changing reflection direction from the wall. In this study, the design method of non-resonance type metamaterial to control reflection sound has been studied by using FEM and Transfer-function method, and to verify the design method, element test was conducted. Element test result correspond well with analysis result, and the design method of acoustic metamaterial has been verified in this study. In order to put into practical use, further study with actual product shape is needed to confirm manufacturability.
\end{abstract}

Keywords : Metamaterial, Reflection, Sound control, Effective density, Effective bulk modulus

\section{1. 緒言}

メタマテリアル(metamaterial)とは「material(材料)」に「meta(超越した)」という接頭語が付けられた造語であり， 自然界に存在する材料が通常示さない特性を持つように人工的に作られた材料のことである. メタマテリアルの 概念については初めに電磁気分野で提唱され(Veselago, 1968), 20 世紀末に分割リング共振器により実現可能であ ることが実証されて以来(Pendry et al., 1996, 1999, Smith et al., 2000), 多くの研究が進められてきた. その後, メタ マテリアルは電磁気分野から音響・振動・熱などの分野に展開され, 夫々の分野で研究が進められている(Kadic et al., 2013).

音響分野では金属球をシリコンゴムでコーティングしたものをエポキシ樹脂内に周期配列することで負の体積 弾性率を持つことが示されてから(Liu et al., 2000), 急速に研究が拡大し, 負の密度を持つメタマテリアル(Zhang et al., 2008), 負の体積弾性率を持つメタマテリアル(Fang et al., 2006), 密度・体積弾性率ともに負となるメタマテリ アル(Lee et al., 2010)が提唱された。これらは周期的に配列された構成部材のローカル共振や共鳴を用いたもので あり，共振周波数近傍で劇的に見かけの音響物性值を変化させることが可能である. 一方で，これらは共振・共 鳴を利用しているため物性值を変化できる周波数範囲が狭く，対象周波数が広い場合は実用化が難しいという課

No.17-00310 [DOI:10.1299/transjsme.17-00310], J-STAGE Advance Publication date : 1 November, 2017

*1 正員, 三菱重工業 (株) 総合研究所振動研究部振動第一研究室（厂851-0392 長崎県長崎市深堀町 5-717-1）

*2 三菱重工業 (株) 総合研究所振動研究部振動第一研究室

E-mail of corresponding author: yukihide nagayo@mhi.co.jp 
題がある.

この課題に対し, 空気中にサイズ違いの部材を配置することで等価物性值を変化させ，屈折率をコントロール する手法が提案されている(Popa et al., 2009, Zigoneanu et al., 2011). この手法は多孔質材料の特性を評価する場合 に用いられる Biot 理論(Biot, 1956,1962, Schoenberg et al.,1983)と同様の原理であると考えられ，ある媒体中に対象 とする音波の波長に対して十分短い間隔で別の媒体が存在する場合, 音波の伝搬を支配する等価密度，等価体積 弹性率が変化することを利用している. 先行研究(Popa et al., 2009)では混在している部材寸法 a が音波の波長入に 対して $1 / 5$ 以下,つまり $\mathrm{a}<1 / 5 \lambda$ となる周波数範囲であれば概社安定した等価物性值になることが示されている. 従来, このようにある媒体に別の媒体が混在している材料に対しては音響物性值を算出, 若しくは計測すること で音響材料として利用してきた，音響メタマテリアルは従来の手順とは逆に，音速等の音響物性值をコントロー ル寸るために，混在する部材の寸法を積極的に設計することで，必要な “材料”を作り出そうとする概念である と考えられる. この観点から, 本研究で扱っている構造も先行研究(Popa et al., 2009, Zigoneanu et al., 2011, Molerón et al., 2014, Kan et al., 2015, Ren, 2015, Park et al., 2016, Zhu et al., 2017, Dong et al., 2017)では音響メタマテリアルと 呼んでいるため, 本研究でも本構造をメタマテリアルと呼ぶこととする. 本手法では構成部材の共振・共鳴を利 用しないため, 音響物性值の変化幅は共振・共鳴を利用する場合と比較すると小さいものの，物性值が変化する 周波数範囲が広いという利点がある. 騒音対策等で実用化を目指寸場合, 周波数範囲が広いことは大きな利点で あり，非常に有用な手法であるが，これらの研究では透過音の伝搬制御を対象にしており，反射音制御について は評価が行われていない，そこで，本研究では反射音制御についてメタマテリアルの設計手法構築，及びその妥 当性検証を行う。

\section{2. メタマテリアル音響物性值算出}

メタマテリアルによって反射音制御を行うためには, メタマテリアルの音響物性值（密度，体積弹性率）を設 計可能とする必要がある．そこで，先ず形状による音響物性值の変化を FEM 解析により評価する. 図 1 に FEM 解析モデルを示す，空気中に鉄材が配置された場合を想定した解析モデルであり，左端のみ無反射境界とし，他 面は全て剛境界を設定した．使用した物性值を表 1 に示し，表 2 に解析ケースを示す．表 2 に示すように空間幅 L1 と部材幅 a の比である部材比 a /L1 を変化させた場合の評価を実施している. 空間幅 L1一定で部材幅 a を変化 させるほうが設計としては容易であるが，ここでは部材幅 a を一定で空間幅 L1 を変化させて評価を行うことと した．これは適用を想定している対象に関しては，本構造を適用寸る場合に部材幅が一定の方が製造性，コス卜 面から有利であると判断したためであり, 適用対象が異なる場合は部材幅 a を変更した構造の適用も考えうる. また，対象周波数は適用を想定している製品の主成分である $400 \mathrm{~Hz}$ を主対象とする． 1 章に示したように音響物 性值を変化させる原理として, 対象とする音波の波長に対して部材が十分小さいことが前提であり, 部材サイズ は音波の波長に対して少なくとも 1/5 以下にする必要があるため(Popa et al., 2009, Zigoneanu et al., 2011), $400 \mathrm{~Hz}$ の波長である $340 \mathrm{~m} / \mathrm{s} / 400 \mathrm{~Hz}=850 \mathrm{~mm}$ から部材サイズを波長の $1 / 6$ として $140 \mathrm{~mm}$ とした. そのため本構造によ る物性值変化の有効周波数は概ね $500 \mathrm{~Hz}$ 以下で有効であると考える.

本モデルを用いて図 1 の点線部（L1×L3 部）を均質材料と見做し，等価物性值の算出を行っていく. 左端面か ら平面波を入力した場合の P1 点，P2 点の音圧レベルを算出し，伝達関数法(Utsuno et al., 1989)を用いて評価を行 った.ここで P1-P2 間距離は対象音波の波長に対して 0.45 倍以下とする必要がある(日本規格協会, 2007). また, 伝達関数法を適用寸るため, 表 2 に示すように部材背後の空気長さ L4 は 2 種類 $(56 \mathrm{~mm}, 35 \mathrm{~mm})$ で解析を行っ た．ここで，背後空気層寸法は $56 \mathrm{~mm}$ と $35 \mathrm{~mm}$ としたが，背後層で共鳴が起きないように対象音波の波長入に 対して入/2 未満となるよう設定すれば同様の結果が得られると考えられる.

図 2 に部材比に対寸る等価密度比, 図 3 に等価体積弾性率比, 図 4 に音速比を示寸. ここでの比率は空気に対 する部材 $(\mathrm{L} 1 \times \mathrm{L} 3$ 部）の密度，体積弾性率，音速の比を示しており，1であれば空気と同じ特性であることを示 している. 代表周波数として $100 \mathrm{~Hz} \sim 400 \mathrm{~Hz}$ の場合を示しているが，周波数毎に僅かに変化するものの，大きな 変化はない. また, 体積弾性率比は部材比が増加しても変化しないのに対し, 密度比は部材比増加に伴い増加寸 る傾向にある. 音速比は体積弾性率比がほぼ一定で, 密度比が増加するため, 部材比の増加に伴って減少する傾 向にある. 図 5 に周波数毎の音速比を示す. 各線は部材比違いを示している. 音速比は部材比毎に変化し, 周波 
Nagayo, Hosoya and Nakano, Transactions of the JSME (in Japanese), Vol.83, No.855 (2017)

数変化の影響は小さい．このことから空間に対する部材比を変えることで音速を設計できることが分かる．また その音速変化は周波数に対しての感度が低く，ブロードな周波数範囲に対して適用寸ることが可能である.

Table 1 FEM analysis parameter

\begin{tabular}{c|c|c|c|c|}
\hline \hline & $\begin{array}{c}\text { Density } \\
\rho\left[\mathrm{kg} / \mathrm{m}^{3}\right]\end{array}$ & $\begin{array}{c}\text { sound } \\
\text { velocity } \\
c[\mathrm{~m} / \mathrm{s}]\end{array}$ & $\begin{array}{c}\text { Young's } \\
\text { modulus } \\
E[\mathrm{GPa}]\end{array}$ & $\begin{array}{c}\text { Poisson ratio } \\
v\end{array}$ \\
\hline Air & 1.23 & 340 & - & - \\
Steel & 7850 & - & 206 & 0.3
\end{tabular}

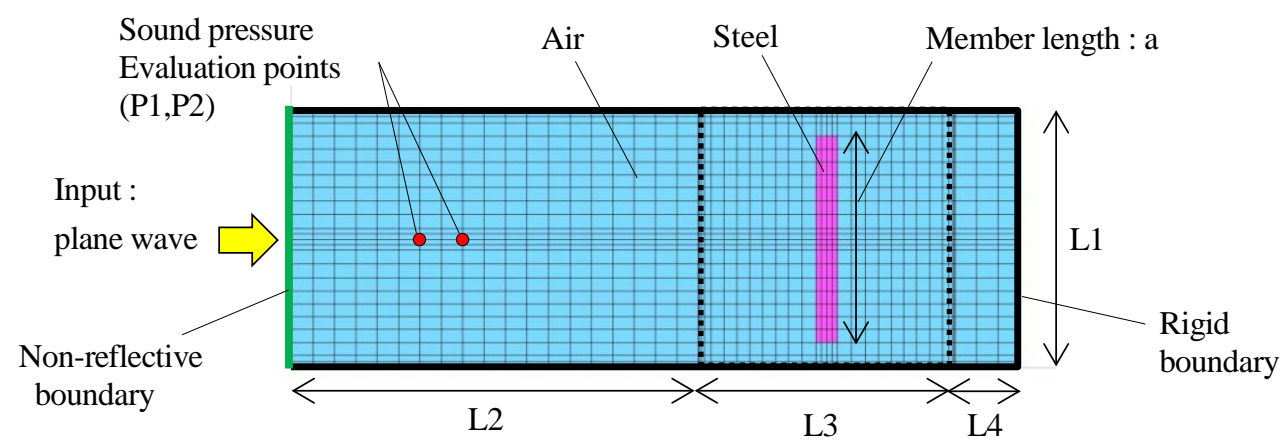

Fig. 1 FEM model for evaluating acoustic characteristics

Table 2 FEM analysis case

\begin{tabular}{c|c|c|c|c|c|c|}
\hline \hline Case & $\begin{array}{c}\text { Member ratio } \\
\text { a / L1 }\end{array}$ & $\begin{array}{c}\text { Member } \\
\text { length } \\
\text { a [mm] }\end{array}$ & $\begin{array}{c}\text { Air width } \\
\text { L1[mm] }\end{array}$ & $\begin{array}{c}\text { Air length } \\
\text { L2[mm] }\end{array}$ & $\begin{array}{c}\text { Air length } \\
\text { L3[mm] }\end{array}$ & $\begin{array}{c}\text { Air length } \\
\text { L4[mm] }\end{array}$ \\
\hline 1 & 0.99 & 140 & 141 & 282 & 140 & 56 and 35 \\
2 & 0.98 & 140 & 143 & 286 & 140 & 56 and 35 \\
3 & 0.95 & 140 & 147 & 294 & 140 & 56 and 35 \\
4 & 0.9 & 140 & 155 & 310 & 140 & 56 and 35 \\
5 & 0.8 & 140 & 175 & 350 & 140 & 56 and 35 \\
6 & 0.7 & 140 & 200 & 400 & 140 & 56 and 35 \\
7 & 0.5 & 140 & 280 & 560 & 140 & 56 and 35 \\
8 & 0.3 & 140 & 466 & 932 & 140 & 56 and 35
\end{tabular}

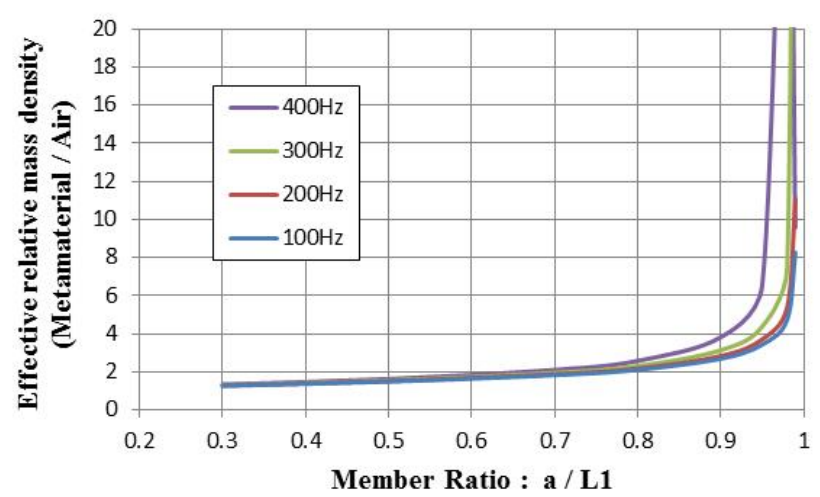

Fig. 2 Effective relative mass density

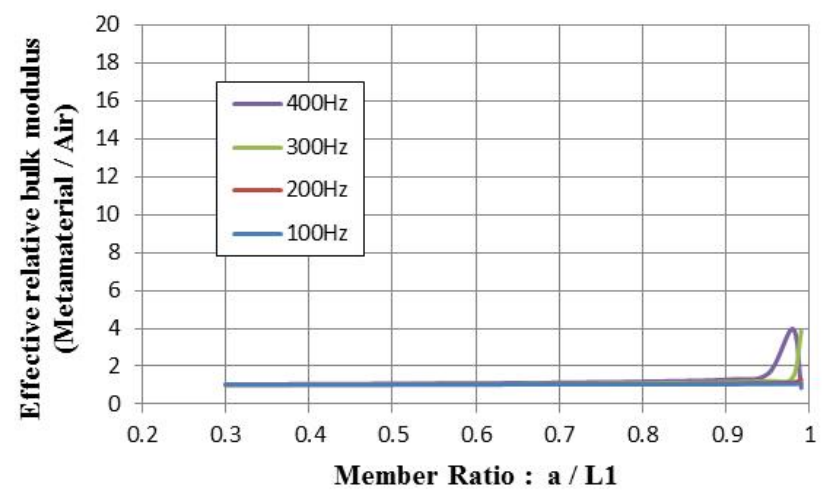

Fig. 3 Effective relative bulk modulus 


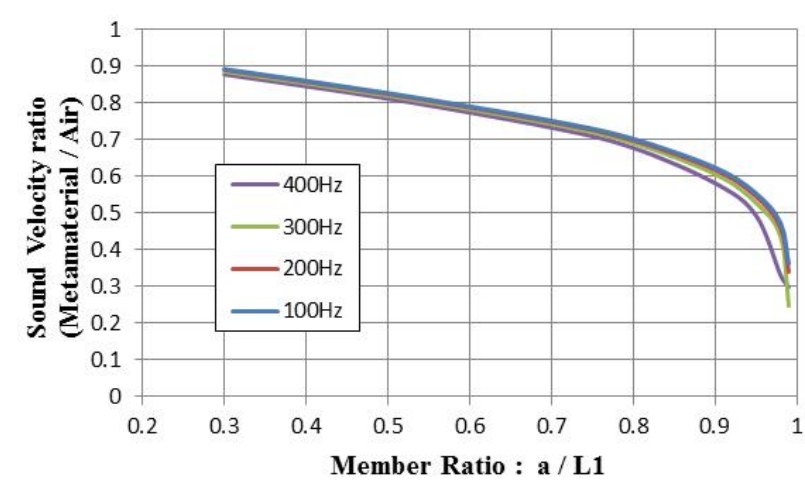

Fig. 4 Sound velocity ratio related to member ratio

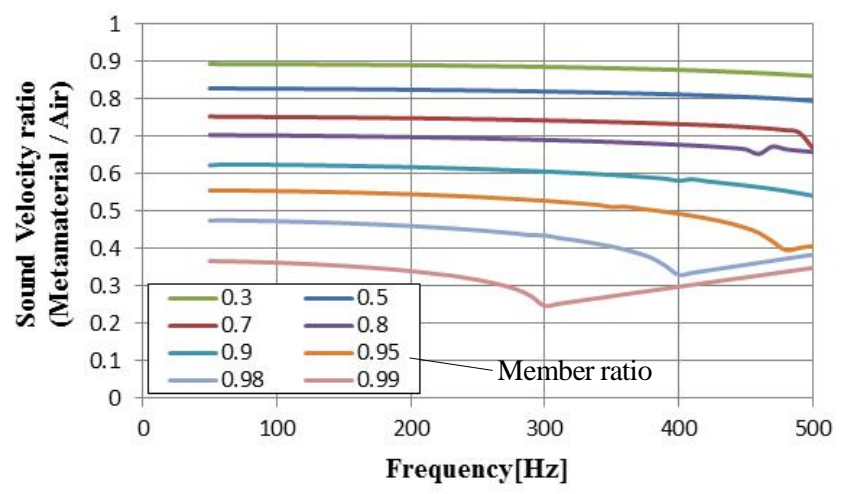

Fig. 5 Sound velocity ratio related to frequency

\section{3.メタマテリアル設計・解析評価}

\section{$3 \cdot 1$ メタマテリアル反射音制御デバイス設計}

2 章で算出した部材比と音速比の関係を用いて反射音を制御するメタマテリアルデバイスの設計を行う. 図 6 に反射音制御の原理を示寸．デバイスに音が入射した場合，デバイス音速が遅い部分に対しデバイス音速が早い 部分からは反射音が早く放出される．そのためデバイス出口面で反射音に位相差が生じ反射方向が変化すること になる. そのため, 必要な反射音方向となるようにデバイスに音速分布をつけることで反射音制御が可能となる.

ここでは暫定的に反射方向を 45 度変化させるデバイス設計を行う. 反射角度はデバイス幅を L ， デバイス厚 さを $\mathrm{t}$, 最大屈折率（音速の逆数）を $n_{\max }$ とすると式(1)で算出できるため(Popa et al., 2009), デバイスサイズを $\mathrm{L}=1400 \mathrm{~mm}, \mathrm{t}=400 \mathrm{~mm}$ とすると屈折率 $\mathrm{n}=2.3$ で $\fallingdotseq 43.6^{\circ}$ となる．ここで屈折率を大きくすればするほどデバイス を薄くすることが可能であるが，屈折率を上げるためには音速を低下させる必要があり，図 4 に示したように部 材比 a /L1 を大きく寸る必要がある. 部材比が大きいと空間 L1 と部材幅 a の隙間が非常に小さくなり，製造が困 難となるため，4 章に示す要素試験供試体製造において現実的な範囲で屈折率を設定した.

$$
\theta=2 \arcsin \left[\frac{t}{L}\left(n_{\max }-1\right)\right]
$$

図 7 に主対象周波数である $400 \mathrm{~Hz}$ での部材比毎の音速比，図 8 にデバイス寸法に対する屈折率，図 9, 表 3 に デバイス設計結果を示す.デバイスは図 9 に示すように(1)（8)に分割された空間の中心部に $140 \mathrm{~mm}$ 幅の部材が 配置された構造である. 反射音方向を 45 度変化させるためには, 図 8 に示寸ようにデバイス内の屈折率を線形的 に 1 から 2.3 まで変化するように設計する必要がある. そのため, 図 7 に示す部材比 $\mathrm{a} / \mathrm{L} 1$ と音速 (屈折率の逆数) の関係を用いて所望の屈折率になるように部材比を(1)〜8)まで選定することでデバイスを設計した. 例えば(8)で あれば，図 8 から屈折率 1.2 (音速 0.83）が必要であるため, 図 7 で縦軸に示した音速が 0.83 となるよう部材比 a /L1 を 0.48 とし, 部材幅aは 140 mm 固定であることから表 3 に示すように空気幅 L1 を 290 mm に決定している.

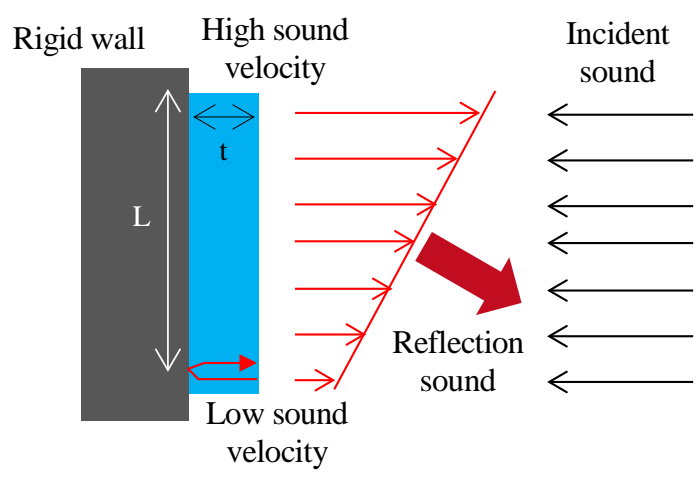

Fig. 6 Reflection sound control method

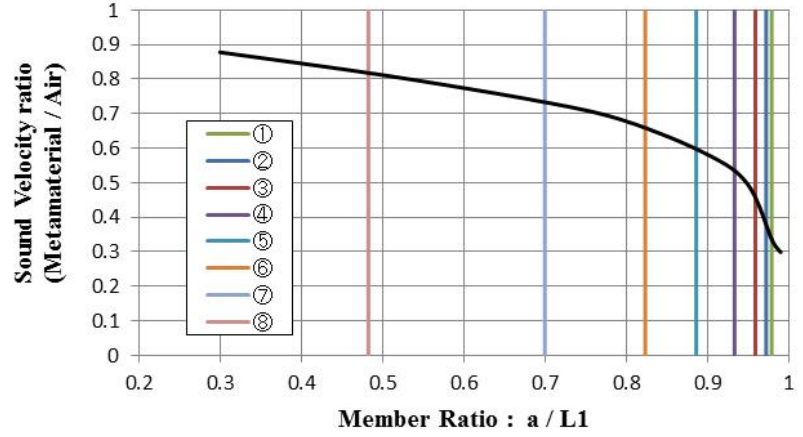

Fig. 7 Sound velocity ratio of $400 \mathrm{~Hz}$ 


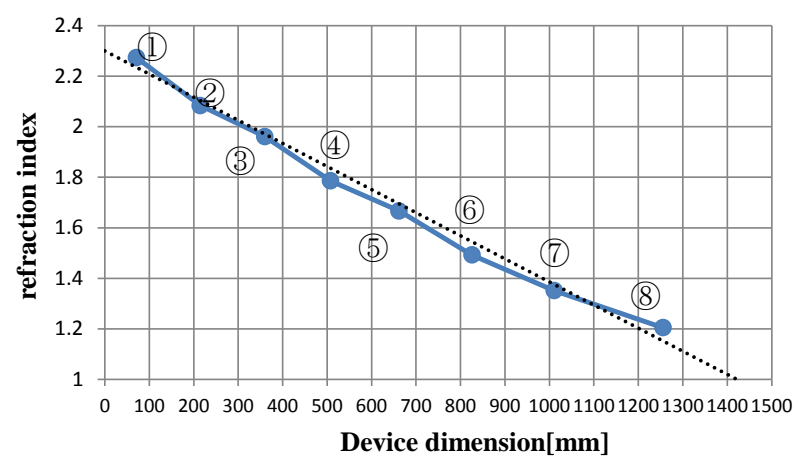

Fig. 8 Relation between device dimension and reflection index

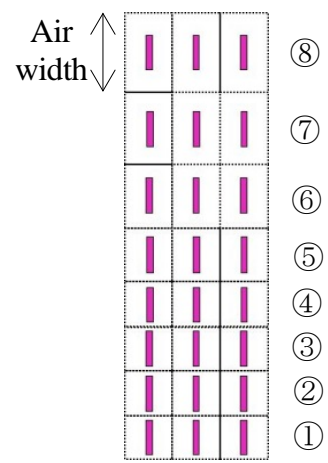

Fig. 9 Device composition
Table 3 Device dimension

\begin{tabular}{c|c|}
\hline \hline & $\begin{array}{c}\text { Air width } \\
\text { L1 [mm] }\end{array}$ \\
\hline (8) & 290 \\
$(7)$ & 200 \\
$(6)$ & 170 \\
$(5)$ & 158 \\
$(4)$ & 150 \\
$(3)$ & 146 \\
$(2)$ & 144 \\
(1) & 143
\end{tabular}

\section{$3 \cdot 2$ 反射音制御効果確認解析}

設計した反射音制御デバイスの効果を FEM 解析で確認する．本節でも説明の都合上，主要対象周波数である $400 \mathrm{~Hz}$ に限定して説明する. 図 10, 図 11 にメタマテリアル有無それぞれの場合の FEM 解析モデルを示す. モデ ルサイズは全て横 4.8m, 縦 $6.4 \mathrm{~m}$ である. 反射音振幅を算出するため 2 種類の解析モデルを作成しており，(a)モ デルはデバイスの背面箇所のみ剛境界，他面は全て無反射境界を設定し，右端面中央部に点音源 $(400 \mathrm{~Hz}$ )入力 した場合の音響構造連成解析モデルであり，点音源からの入射波とデバイスからの反射波が算出される. (b)モデ ルは全面無反射境界を設定しており，点音源からの入射波のみが算出される．反射音のみを評価するため，(a)モ デルで算出した複素音速から(b)モデルで算出した複素音速を差し引くことで反射音のみの音圧振幅を算出した. デバイスからの反射音振幅算出過程を図 12 , 図 13 を用いて説明する。左図が(a)モデルの結果，中図が(b)モデル の結果であり, 左図から中図を差し引いたものが右図であり, デバイスからの反射音振幅を算出している.コンタ 一は音圧の大きさを示しており，全て同じレンジで表示している. 図 14 に反射音の指向特性を示す。図 10(a), 図 11(a)に評価点を示しているように 10 度ピッチで半径 $1.5 \mathrm{~m}$ 点の音圧を最大值を 1 に正規化して示している. 剛 壁の反射音は当然ながら法線方向へ反射しており，メタマテリアルデバイス有りの場合には反射音が約 $45^{\circ}$ 下向 きに変化していることからメタマテリアルの設計手法は妥当であることを確認した.

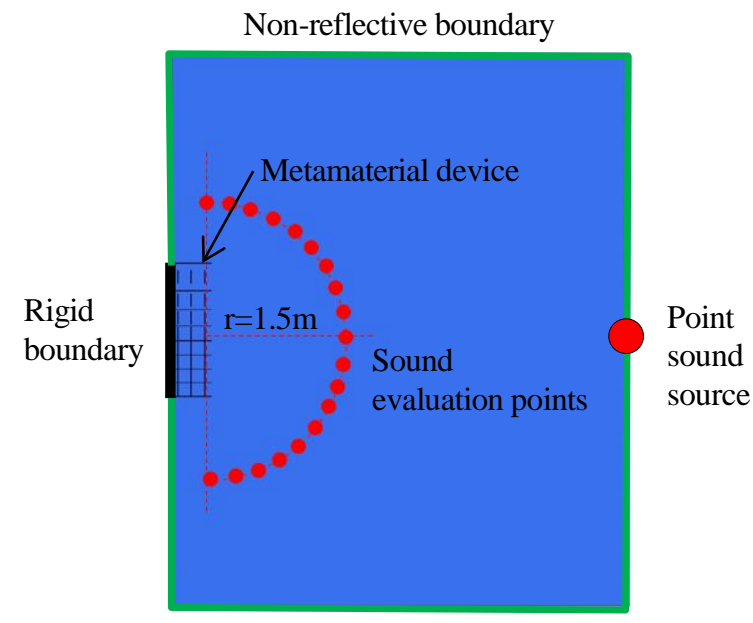

Non-reflective boundary

(a) Model for incident and reflection wave

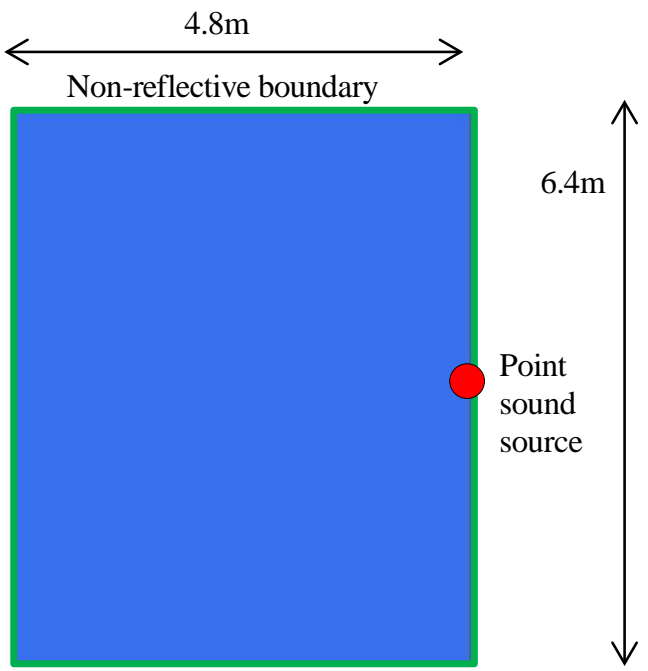

Non-reflective boundary

(b) Model for incident wave

Fig.10 FEM analysis model with metamaterial device 


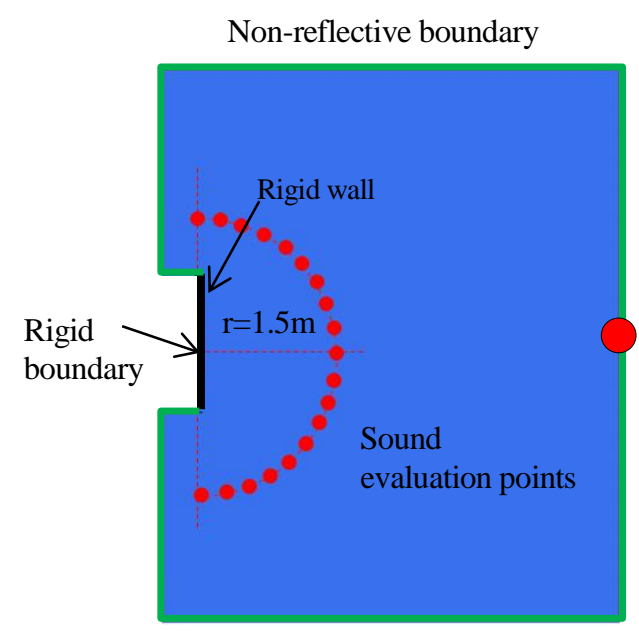

Non-reflective boundary

(a) Model for incident and reflection wave

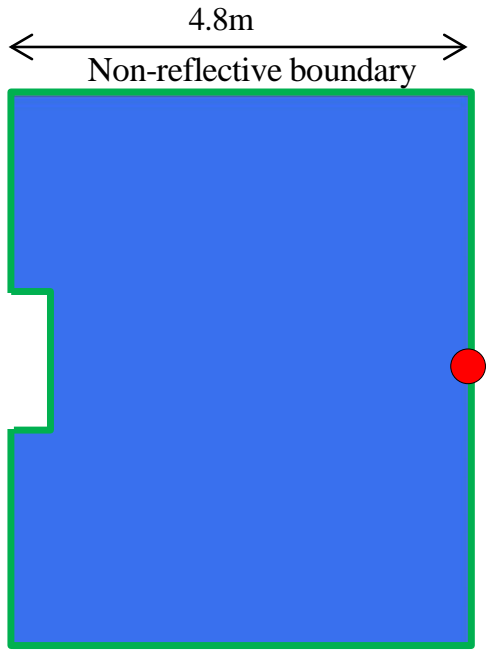

Non-reflective boundary

(b) Model for incident wave

Fig.11 FEM analysis model without metamaterial device
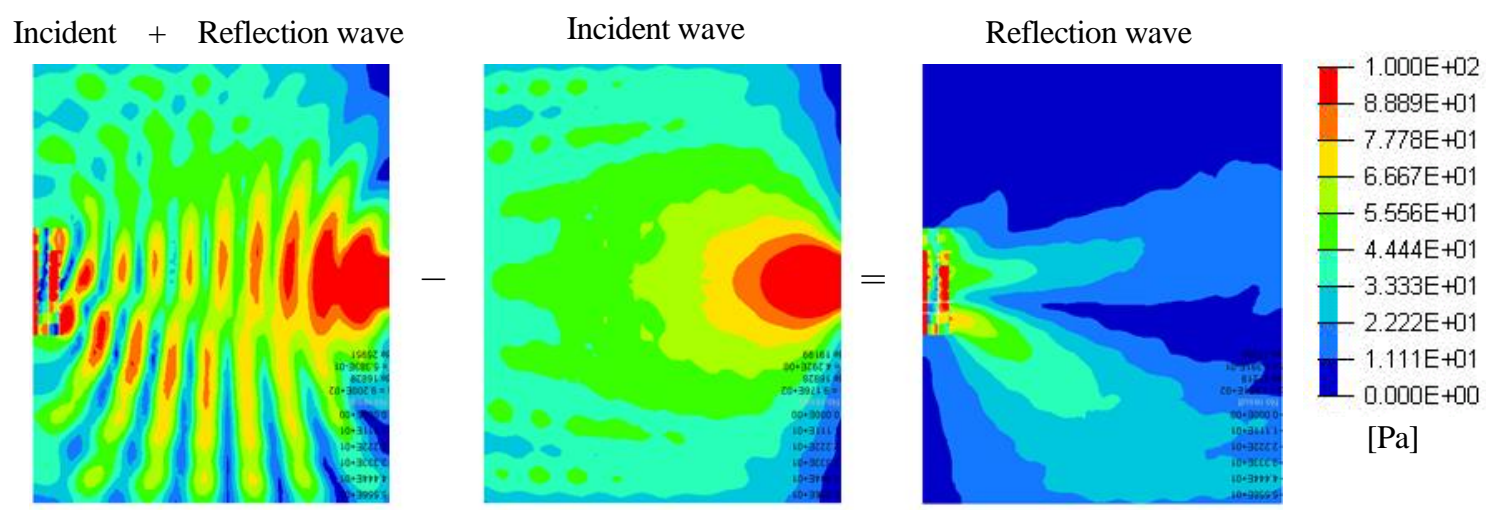

sound

sound

source

Fig.12 FEM analysis result with metamaterial device
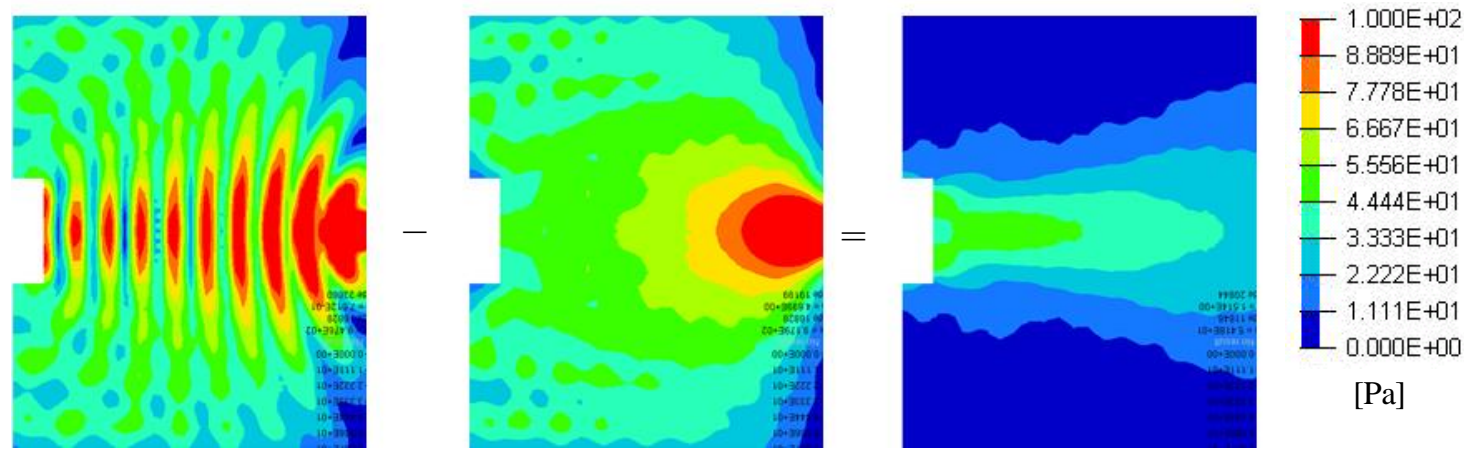

[Pa]

Fig.13 FEM analysis result without metamaterial device 


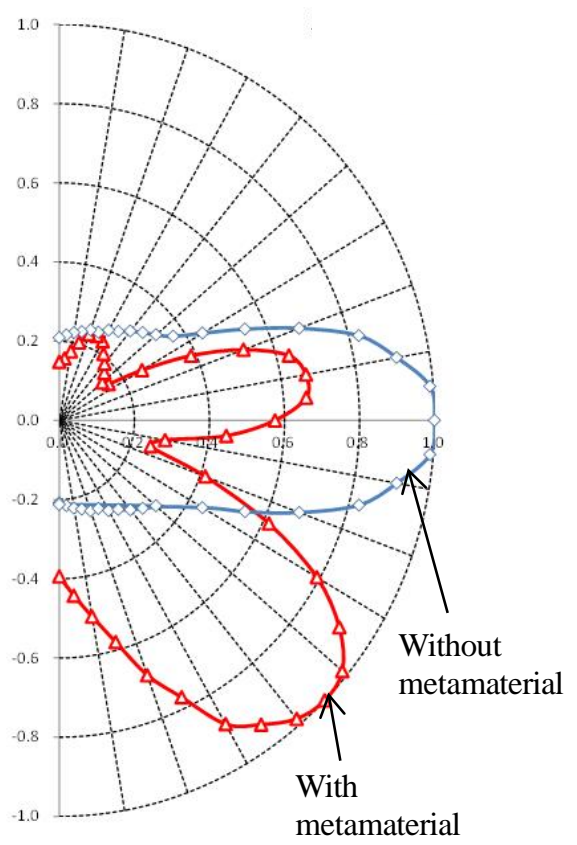

Fig. 14 Directional characteristic by FEM analysis result

\section{4. メタマテリアル設計の妥当性検証試験}

メタマテリアルによる反射音制御デバイス設計の妥当性を検証するため, 試作品を製作し要素検証試験を実施 した．試作品を図 15 に示し，試験セットアップを図 16 に示す。メタマテリアルデバイスを無響室に設置し，供 試体表面 (メタマテリアル有)，裏面（メタマテリアル無）からの反射音指向特性を計測した。メタマテリアルか

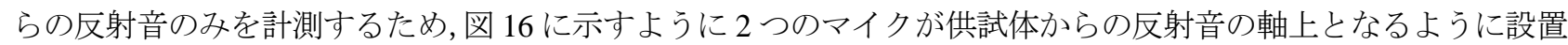
し, 半径 $1.5 \mathrm{~m}$ の半円上を移動しながら計測を実施した後, 2 点の音圧実測值から反射音のみを切分けて評価を 行った. 反射音は図 17 に示寸ようにマイク 1 , マイク 2 に対して入射波が角度 $\theta$ で入射し, 反射波がマイク 1 と マイク 2 の軸上を通ると寸ると式(2)で算出できる. ここで，マイク 1 の複素音圧を $\mathrm{P} 1$ ，マイク 2 の複素音圧を $\mathrm{P} 2$ ，マイク間距離を $\mathrm{d} ，$ 波数を $\mathrm{k}$ とた.

$$
P_{b}=\frac{P_{2}-P_{1} e^{-j k d \cos \theta}}{e^{j k d}-e^{-j k d \cos \theta}}
$$

主対象周波数である $400 \mathrm{~Hz}$ の評価結果を図 18 に示寸. 図 14 と同様に 10 度ピッチで半径 $1.5 \mathrm{~m}$ 点の音圧を最大 值 1 に正規化して示している.メタマテリアル無しの場合（剛壁の場合）の反射音指向性は解析と試験結果でよ く一致しており，計測手法が妥当であることを確認した．またメタマテリアル有りの場合の指向性についても解 析と試験結果が良く一致しており, メタマテリアル設計手法が妥当であることを確認した.

ここで, 本デバイスの他周波数の特性として $300 \mathrm{~Hz}$ と $500 \mathrm{~Hz}$ の評価結果を図 19, 図 20 に示す. 2 章に記載し たように部材幅が対象音波の波長に対して概ね $1 / 5$ 以下である周波数範囲では本手法は有効であると考えられ， $300 \mathrm{~Hz}, 500 \mathrm{~Hz}$ でも反射角度は下向きに変化する傾向にあり FEM 解析結果とも良好に一致している. しかしなが ら $400 \mathrm{~Hz}$ と比較すると反射角度が浅くなっている. これは図 5 に示したように周波数毎に等価音速が若干異なる ことが影響していると考えられる. 

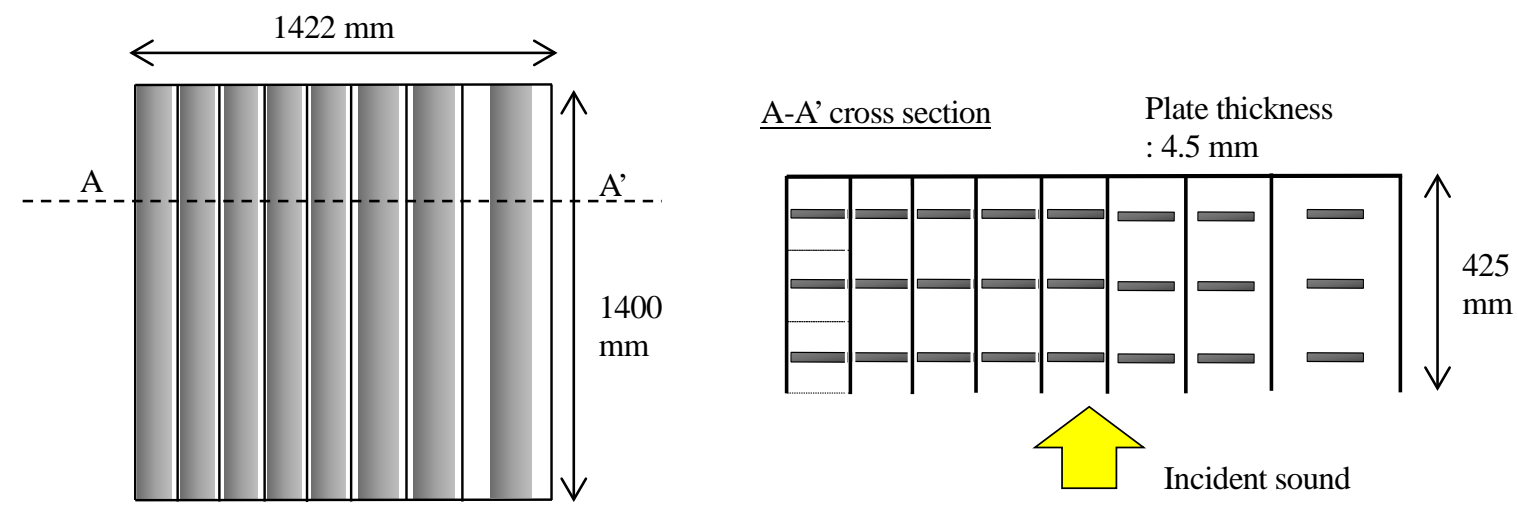

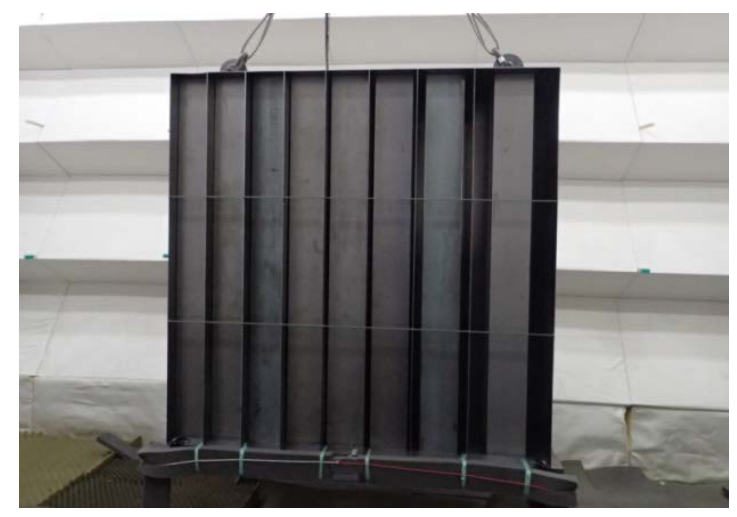

(a) Front side

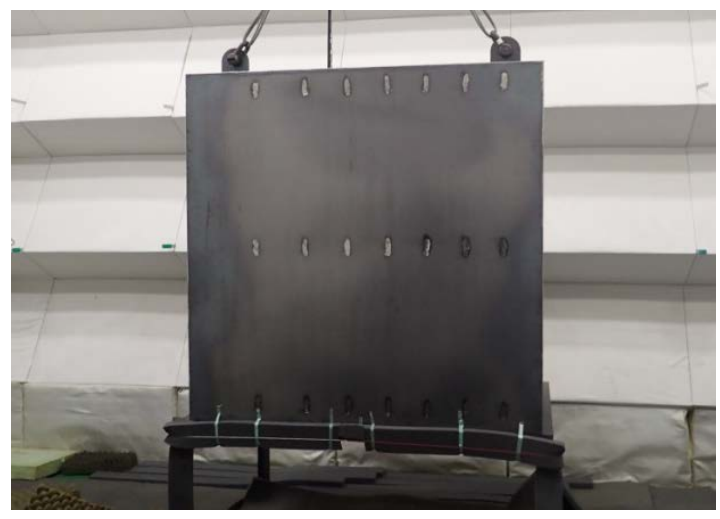

(b) Back side

Fig. 15 Element test piece
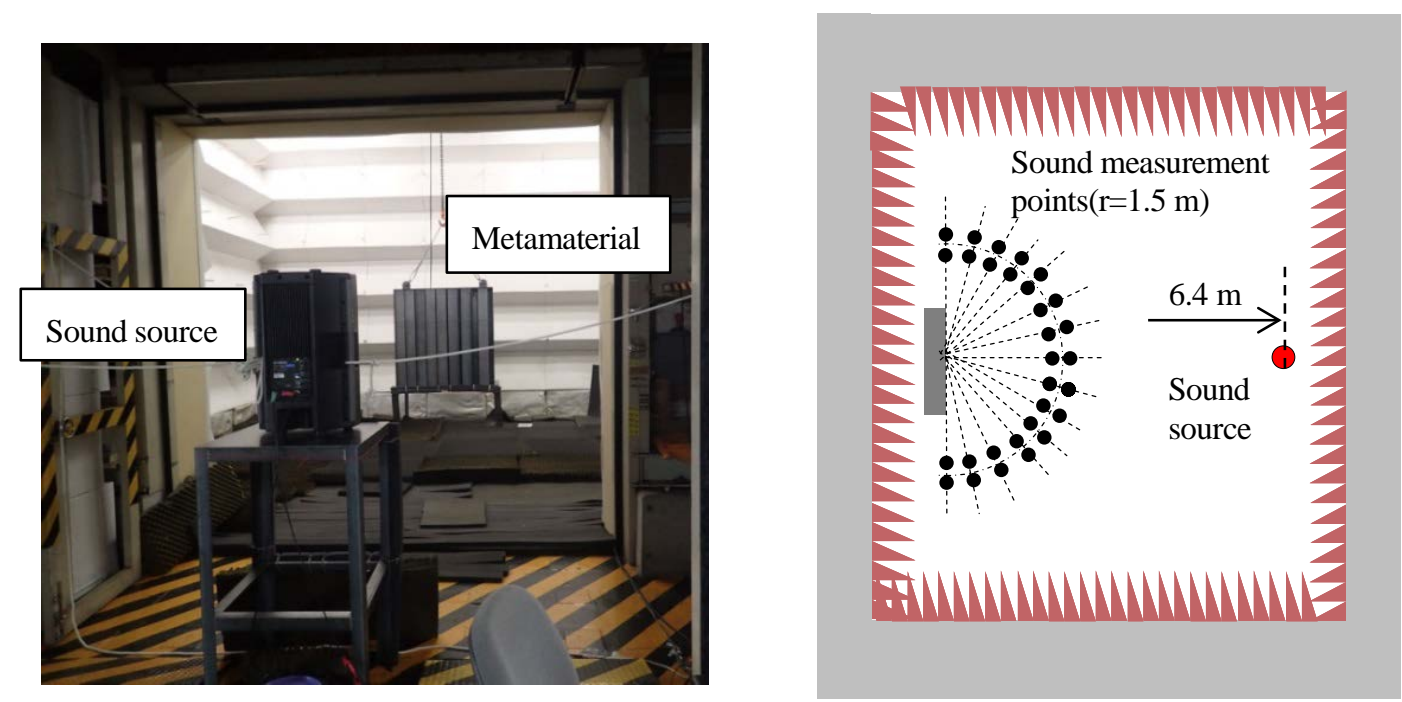

Fig. 16 Test configuration

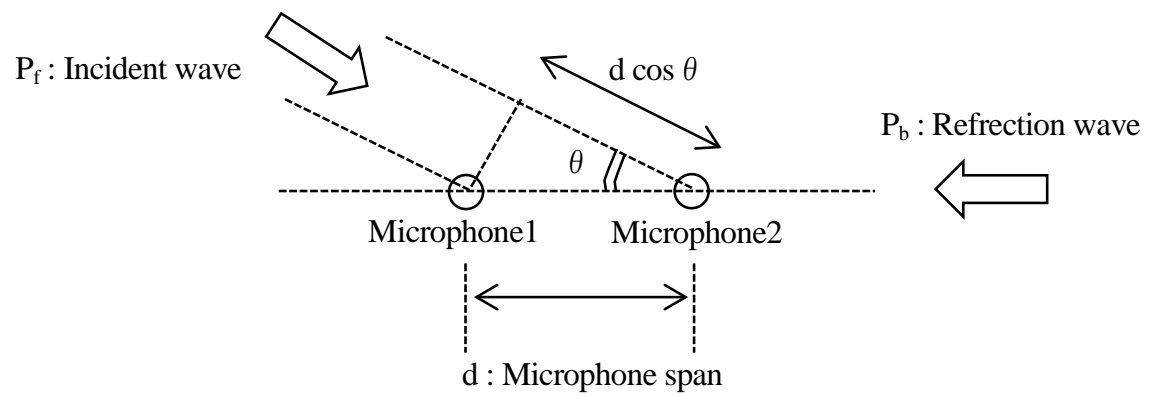

Fig. 17 Refrection wave calculation model 


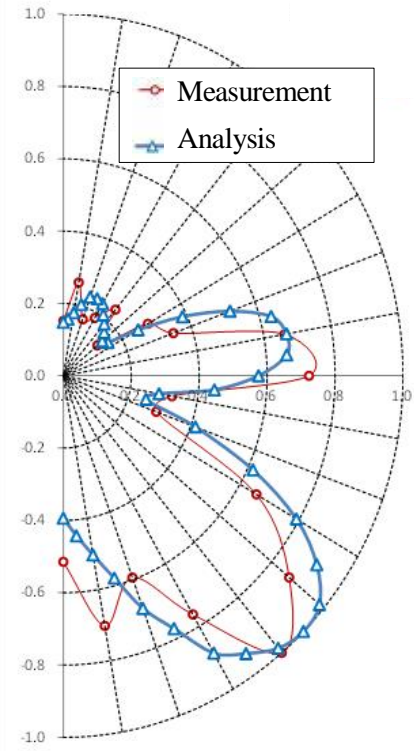

(a) With metamaterial device

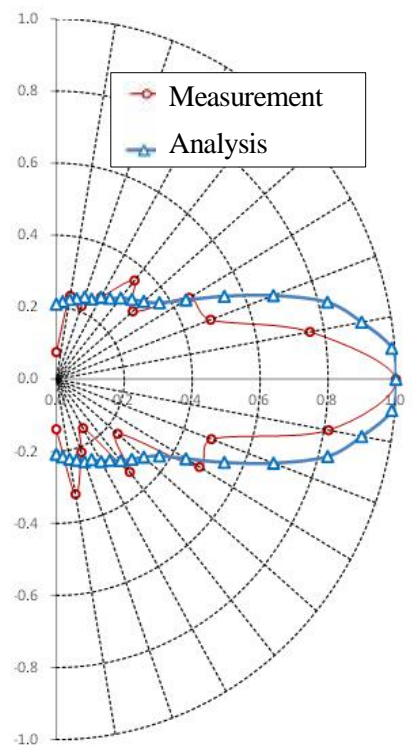

(b) Without metamaterial device

Fig. 18 Comparison between analysis and test result $(400 \mathrm{~Hz})$

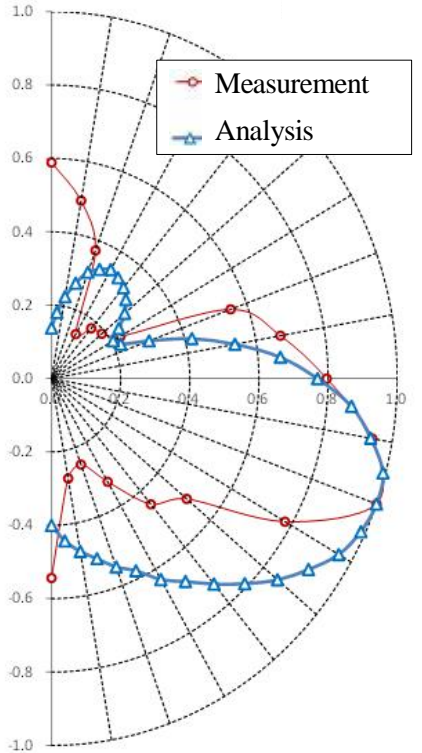

Fig. 19 Comparison between analysis and test result $(300 \mathrm{~Hz})$

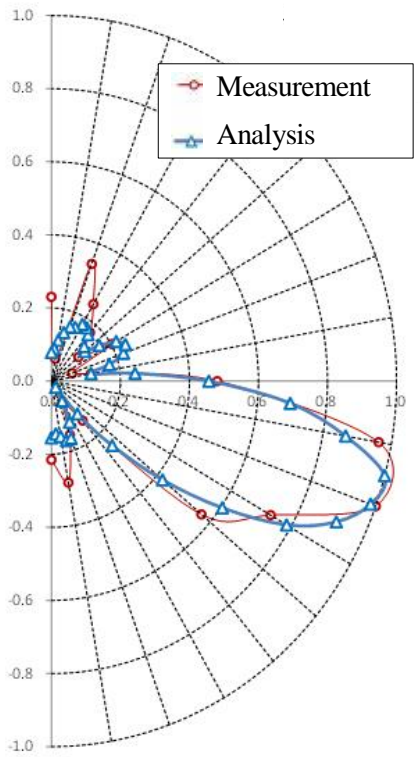

Fig. 20 Comparison between analysis and test result $(500 \mathrm{~Hz})$

\section{5. 結 言}

広周波数に適用可能な共振を利用しない音響メタマテリアルについて，これまで透過音については評価がなさ れていたものの，反射音については設計手法・評価手法の検討がなされていなかった．本研究では音響メタマテ リアルを用いた反射音制御手法を構築するため, メタマテリアル音響特性算出，メタマテリアルデバイス設計， 音場制御効果確認を FEM 解析により実施し，試作品による要素試験で設計手法の妥当性検証を実施した。要素 試験で取得した反射音指向特性は，FEM解析と良く一致しており，本研究で実施した音響メタマテリアルによる 反射音制御手法が妥当であることを確認した，今後，反射音制御による騷音対策等を実用化するため，実製品に 近い形状での評価，及び製造方法の簡略化検討が必要であると考えている. 


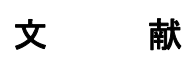

Biot, M.A., Theory of propagation of elastic waves in a fluid - saturated porous solid. i. low - frequency range, The Journal of the Acoustical Society of America, 28, 168 (1956).

Biot, M.A., Mechanics of deformation and acoustic propagation in porous media, The Journal of the Acoustical Society of America, 33, 1482 (1962).

Dong, H.Y., Cheng, Q., Song, G.Y., Tang, W.X., Wang, J. and Cui, T.J., Realization of broadband acoustic metamaterial lens with quasi-conformal mapping, Applied Physics Express, 10, 087202 (2017).

Fang, N., Xi, D., Xu, J., Ambati, M., Srituravanich, W., Sun, C. and Zhang, X., Ultrasonic metamaterials with negative modulus, Nature Materials, Vol.5 (2006), pp.452-456.

日本規格協会，音響管による吸音率及びインピーダンスの測定-第 2 部 : 伝達関数法, JIS A 1405-2 (2007).

Kadic, M., Buckmann, T., Schittny, R. and Wegener, M., Metamaterials beyond electromagnetism, Reports on Progress in physics, Vol.76 (2013) Number12.

Kan, W., Garcia-Chocano, V.M., Cervera, F., Liang, B., Zou, X., Yin, L., Cheng, J. and Sanchez-Dehesa, J., Broadband acoustic cloaking within an arbitrary hard cavity, Physical Review Applied, 3, 064019 (2015).

Liu, Z., Zhang, X., Mao, Y., Zhu, Y.Y., Yang, Z., Chan, C.T. and Sheng, P., Locally resonant sonic materials, Science, Vol.289, No.5485 (2000), pp.1734-1736.

Lee, S.H., Park, C.M., Seo, Y.M., Wang, Z.G. and Kim, C.K., Composite acoustic medium with simultaneously negative density and modulus, Physical Review Letters, 104054301 (2010).

Molerón, M.,Serra-Garcia, M. and Daraio,C., Acoustic fresnel lenses with extraordinary transmission, Applied Physics Letters, 105, 114109 (2014).

Park, J.H., Lee, H.J. and Kim, Y.Y., Characterization of anisotropic acoustic metamaterial slabs, Journal of Applied Physics, 119, 034901 (2016).

Pendry, J.B., Holden, A.J., Stewart, W.J. and Youngs, I., Extremely low frequency plasmons in metallic mesostructures, Physical Review Letters, Vol.76, No.25 (1996), pp.4773-4776.

Pendry, J.B., Holden, A.J., Robbins, D.J. and Stewart, W.J., Magnetism from conductors and enhanced non-linear phenomena, IEEE Transaction on Microwave Theory and Techniques, Vol.47, No.11 (1999), pp.2075-2084.

Popa, B.I. and Cummer, S.A., Design and characterization of broadband acoustic composite metamaterials, Physical Review B 80, 174303 (2009).

Ren, C., Compact acoustic antenna design using labyrinthine metamaterials, Applied Physics A, 119, 461-465 (2015).

Schoenberg, M. and Sen, P.N., Properties of a periodically stratified acoustic half-space and its relation to biot fluid, The Journal of the Acoustical Society of America, 73,61 (1983).

Smith, D.R., Pedilla, W.J., Vier, D.C., Nemat-N., S.C. and Schultz, S., Composite medium with simultaneously negative permeability and permittivity, Physical Review Letters, Vol.84, No.18 (2000), pp.4184-4187.

Utsuno, H., Tanaka, T. and Fujioka, T., Transfer function method for measuring characteristic impedance and propagation constant of porous materials, The Journal of the Acoustical Society of America, Vol.86, 637 (1989).

Veselago, V.G., The electrodynamics of substances with simultaneously negative values of $\varepsilon$ and $\mu$, Soviet Physics Uspekhi, Vol.10, No.4(1968), pp.509-514.

Zhang, X., Mei, J., Yang, M. and Sheng, P., Membrane-type acoustic metamaterial with negative dynamic mass, Physical Review Letters, 101, 204301 (2008).

Zhu, R., Ma, C., Zheng, B., Musa, M.Y., Jing, L., Yang, Y., Wang, H., Dehdashti, S., Fang, N.X. and Chen, H., Bifunctional acoustic metamaterial lens designed with coordinate transformation, Applied Physics Letters, 110, 113503 (2017).

Zigoneanu, L., Popa, B.I. and Cummer, S.A., Design and measurements of a broadband two-dimensional acoustic lens, Physical Review B 84, 024305 (2011).

Zigoneanu, L., Popa, B.I., Starr, A.F. and Cummer, S.A., Design and measurements of a broadband two-dimensional acoustic metamaterial with anisotropic effective mass density, Journal of applied physics, 109, 054906 (2011). 


\section{References}

Biot, M.A., Theory of propagation of elastic waves in a fluid - saturated porous solid. i. low - frequency range, The Journal of the Acoustical Society of America, 28, 168 (1956).

Biot, M.A., Mechanics of deformation and acoustic propagation in porous media, The Journal of the Acoustical Society of America, 33, 1482(1962).

Dong, H.Y., Cheng, Q., Song, G.Y., Tang, W.X., Wang, J. and Cui, T.J., Realization of broadband acoustic metamaterial lens with quasi-conformal mapping, Applied Physics Express, 10, 087202 (2017).

Fang, N., Xi, D., Xu, J., Ambati, M., Srituravanich, W., Sun, C. and Zhang, X., Ultrasonic metamaterials with negative modulus, Nature Materials, Vol.5 (2006), pp.452-456.

Japanese Industrial Standard, Acoustics -- Determination of sound absorption coefficient and impedance in impedance tubes -- part 2: transfer-function method, JIS A 1405-2 (2007) (in Japanese).

Kadic, M., Buckmann, T., Schittny, R. and Wegener, M., Metamaterials beyond electromagnetism, Reports on Progress in physics, Vol.76 (2013) Number 12.

Kan, W., Garcia-Chocano, V.M., Cervera, F., Liang, B., Zou, X., Yin, L., Cheng, J. and Sanchez-Dehesa, J., Broadband acoustic cloaking within an arbitrary hard cavity, Physical Review Applied, 3, 064019 (2015).

Liu, Z., Zhang, X., Mao, Y., Zhu, Y.Y., Yang, Z., Chan, C.T. and Sheng, P., Locally resonant sonic materials, Science, Vol.289, No.5485 (2000), pp.1734-1736.

Lee, S.H., Park, C.M., Seo, Y.M., Wang, Z.G. and Kim, C.K., Composite acoustic medium with simultaneously negative density and modulus, Physical Review Letters, 104 054301(2010).

Molerón, M., Serra-Garcia, M. and Daraio, C., Acoustic fresnel lenses with extraordinary transmission, Applied Physics Letters, 105, 114109 (2014).

Park, J.H., Lee, H.J. and Kim, Y.Y., Characterization of anisotropic acoustic metamaterial slabs, Journal of Applied Physics, 119, 034901 (2016).

Pendry, J.B., Holden, A.J., Stewart, W.J. and Youngs, I., Extremely low frequency plasmons in metallic mesostructures, Physical Review Letters, Vol.76, No.25 (1996), pp.4773-4776.

Pendry, J.B., Holden, A.J., Robbins, D.J. and Stewart, W.J., Magnetism from conductors and enhanced non-linear phenomena, IEEE Transaction on Microwave Theory and Techniques, Vol.47, No.11 (1999), pp.2075-2084.

Popa, B.I. and Cummer, S.A., Design and characterization of broadband acoustic composite metamaterials, Physical Review B 80, 174303 (2009).

Ren, C., Compact acoustic antenna design using labyrinthine metamaterials, Applied Physics A, 119, 461-465 (2015).

Schoenberg, M. and Sen, P.N., Properties of a periodically stratified acoustic half-space and its relation to biot fluid, The Journal of the Acoustical Society of America, 73,61 (1983).

Smith, D.R., Pedilla, W.J., Vier, D.C., Nemat-N., S.C. and Schultz, S., Composite medium with simultaneously negative permeability and permittivity, Physical Review Letters, Vol.84, No.18 (2000), pp.4184-4187.

Utsuno, H., Tanaka, T. and Fujioka, T., Transfer function method for measuring characteristic impedance and propagation constant of porous materials, The Journal of the Acoustical Society of America,Vol.86, 637 (1989).

Veselago, V.G., The electrodynamics of substances with simultaneously negative values of $\varepsilon$ and $\mu$, Soviet Physics Uspekhi, Vol.10, No.4 (1968), pp.509-514.

Zhang, X., Mei, J., Yang, M. and Sheng, P., Membrane-type acoustic metamaterial with negative dynamic mass, Physical Review Letters, 101, 204301 (2008).

Zhu, R., Ma, C., Zheng, B., Musa, M.Y., Jing, L., Yang, Y., Wang, H., Dehdashti, S., Fang, N. X. and Chen, H., Bifunctional acoustic metamaterial lens designed with coordinate transformation, Applied Physics Letters, 110, 113503 (2017).

Zigoneanu, L., Popa, B.I. and Cummer, S.A., Design and measurements of a broadband two-dimensional acoustic lens, Physical Review B 84, 024305 (2011).

Zigoneanu, L., Popa, B.I., Starr, A.F. and Cummer, S.A., Design and measurements of a broadband two-dimensional acoustic metamaterial with anisotropic effective mass density, Journal of applied physics, 109, 054906 (2011). 